fluconazole in treatment of cryptococcal meningitis and candida pyelonephritis in rabbits. Antimicrob Agents Chemother 29:579-583

28. Smyth Jr HF, Carpenter CP, Weil CS 1955 The chronic oral toxicology of the polyethylene glycols. J Am Pharm Assoc 44:27-30

29. Chadwick VS, Phillips SF, Hofmann AF 1977 Measurements of intestinal permeability using low molecular weight polyethylene glycols (PEG 400). I. Chemical analysis and biological properties of PEG 400. Gastroenterology 73:241-246

30. Lockard JS, Levy RH, Congdon WC, DuCharme LL 1979 Efficacy and toxicity of the solvent polyethylene glycol 400 in monkey model. Epilepsia 20:7784

31. Mackie K, DePasquale M, Cserr HF 1986 Increased permeability of a glial blood-brain bariier during acute hyperosmotic stress. Am $\mathfrak{J}$ Physiol 251:R1186-R1192

32. Levin VA 1980 Relationship of octanol/water partition coefficient and molecular weight to rat brain capillary permeability. J Med Chem 23:682-684

33. Cornford EM, Braun LD, Oldendorf WH, Hill MA 1982 Comparison of lipidmediated blood-brain-barrier penetrability in neonates and adults. Am J Physiol 243:C161-C168

34. Sundqvist T, Magnusson KE 1985 Modelling of intestinal permeability in man to polyethylene glycols (PEG 400 and PEG 1000). Acta Physiol Scand 125:289-296

35. Fenstermacher JD, Johnson JA 1966 Filtration and reflection coefficients of the rabbit blood brain barrier. Am J Physiol 211:341-346

\title{
Announcements
}

\section{Annual Meeting}

The 4th annual meeting of the Sociedad Latinoamericana de Endocrinologia Pediatrica (SLEP) will be held November 4-9, 1990 in Recife, Brasil. For further information, contact: Secretario General, SLEP, Gallo 1330, 1425 Buenos Aires, Argentina, 54-1-962-4035, FAX: 54-1-962-3762.

\section{Call for Papers}

The North American Primary Care Research Group will hold its 19th annual meeting May 22-25, 1991 in Quebec, Canada. Deadline for submission of abstracts and papers is December 14, 1990. Established researchers, new investigators, practicing physicians, residents, and students are invited to submit papers. Contact NAPCRG conference secretariat at the Continuing Medical Education Office, Faculty of Medicine, Laval University, Quebec, Canada G1K 7P4, (418) 656-5958, FAX: (418) 656-3442. 